\title{
Clinical Reasoning: Recurrent strokes secondary to unknown vasculopathy
}

Ronda Lun, MD, Naomi Niznick, MD, Ruth Padmore, MD, PhD, FRCPC, Jonathan Mack, MD, MSc, FRCPC, Michel Shamy, MD, MA, FRCPC, Grant Stotts, MD, FRCPC, and Dylan Blacquiere, MD, MSc, FRCPC

Neurology ${ }^{\circledR}$ 2020;94:e2396-e2401. doi:10.1212/WNL.0000000000009534

\section{Section 1}

A healthy 84-year-old woman of Chinese ethnicity presented with multiple separate episodes of focal neurologic deficits (right-sided weakness with aphasia, as well as left-sided weakness) over 2 days, in the context of 3 months of subacute cognitive decline. She had been well leading up to this presentation. CT angiogram showed multifocal constriction of the middle cerebral arteries and bilateral M3 occlusions. Posterior circulation vessels were unremarkable. Cerebral MRI with gadolinium showed multiple foci of restricted diffusion in the bilateral frontal and parietal lobes and diffuse T2/fluid-attenuated inversion recovery changes without abnormal enhancement, consistent with infarction of varying ages (figure 1, A). She was started on low-dose acetylsalicylic acid and deep vein thrombosis prophylaxis and admitted to the hospital.

\section{Questions for consideration:}

1. What are your differential diagnoses?

2. What further investigations would you want?
Correspondence

Dr. Lun

rlun@toh.ca

From the Divisions of Neurology (R.L., N.N., M.S., G.S., D.B.) and Hematology (.M.), Department of Medicine, and Division of Hematopathology, Department of Pathology and Laboratory Medicine, Ottawa and Eastern Ontario Regional Laboratory Association (R.P.), The Ottawa Hospital, Canada.

Go to Neurology.org/N for full disclosures. Funding information and disclosures deemed relevant by the authors, if any, are provided at the end of the article. 
Figure 1 Initial and repeat MRI brain, conventional angiogram of our patient
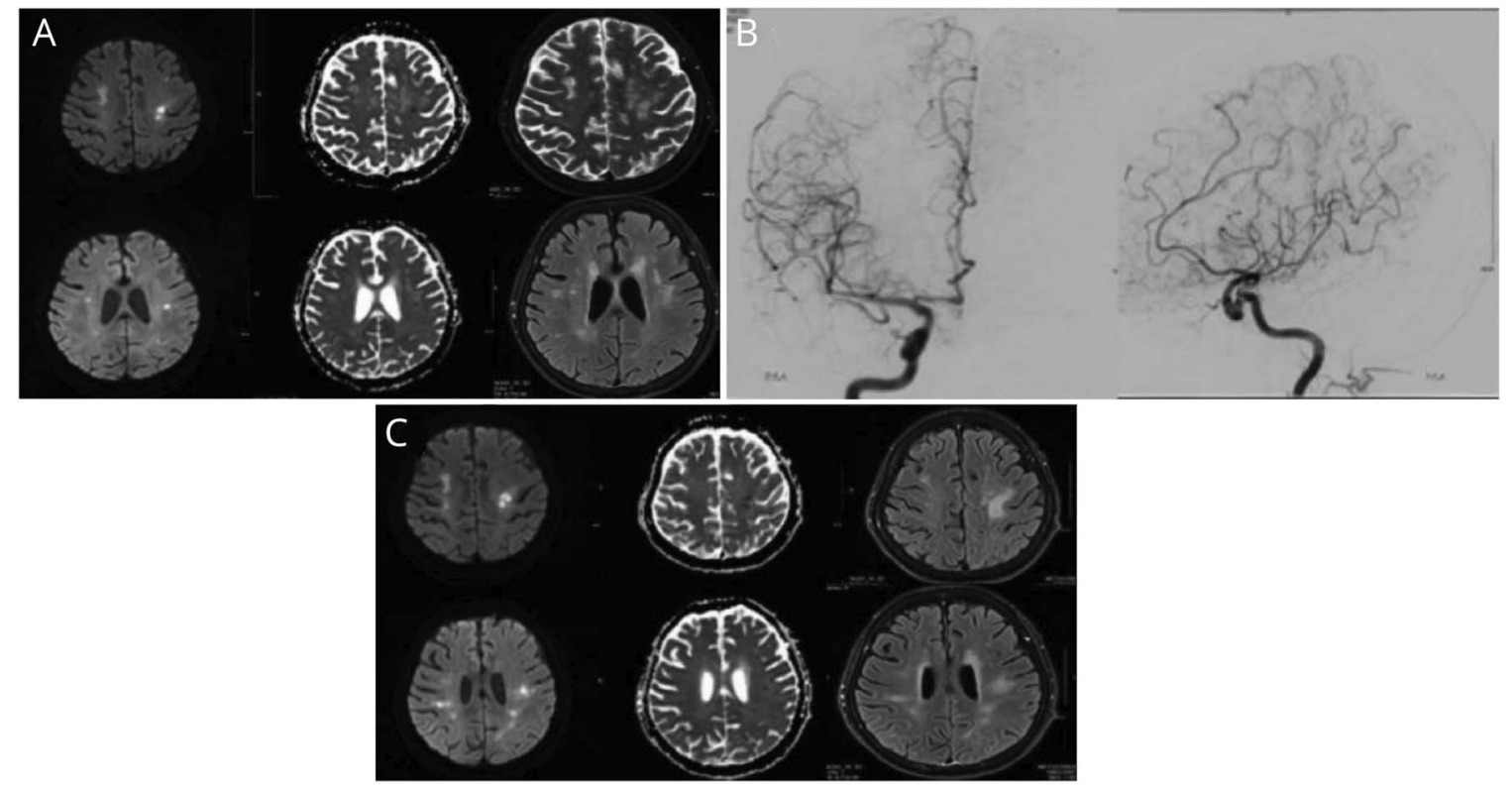

(A) Initial MRI brain demonstrates multiple strokes of different ages. (B) Conventional angiogram images demonstrate diffuse beading of intracranial and extracranial vessels. (C) Repeat MRI brain demonstrates new and old progression of ischemic strokes.

GO TO SECTION 2 


\section{Section 2}

Multiterritorial strokes with vessel beading should raise concern for a vasculopathy, which may include infectious, inflammatory, neoplastic, and vascular processes.

In our patient, a conventional angiogram showed beading of small and medium-sized vessels, both intracranially and extracranially, concerning for a diffuse vasculopathy (figure 1, B). Bloodwork showed elevated inflammatory markers (erythrocyte sedimentation rate 115, C-reactive protein 56.1), but negative testing for rheumatologic, hypercoagulable, and infectious processes including antiphospholipid antibody syndrome and HIV. CSF analysis demonstrated 2 total nucleated cells, normal glucose of $2.3 \mathrm{mmol} / \mathrm{L}$, elevated protein at $1.46 \mathrm{~g} / \mathrm{L}$ (normal, $0.18-0.68$ ), and elevated albumin at 0.96 $\mathrm{g} / \mathrm{L}$ (normal, 0.14-0.25). Identical oligoclonal immunoglobulin G banding was present in both serum and CSF, suggestive of increased permeability of the blood-brain barrier. CSF cytology was negative. CT of the chest, abdomen, and pelvis showed no solid organ malignancy or lymphadenopathy, and paraneoplastic antibodies were negative. Serum and urine electrophoresis were unremarkable. Bilateral temporal artery biopsies were inconclusive for giant cell arteritis (GCA), demonstrating only nonspecific disruption of internal elastic membranes.

At this point, the following etiologies and diagnoses were considered:

1. Inflammatory vasculopathies

- Medium-vessel vasculitis

- Polyarteritis nodosa (PAN), an ANCA-negative systemic necrotizing vasculitis involving mediumsized vessels, was considered. ${ }^{1}$ Patients typically present with systemic symptoms and multiorgan involvement. Classic neurologic manifestations include peripheral neuropathies, and CNS involvement is seen in only $4 \%-8 \%$ of patients. It would be exceedingly rare for PAN to present with recurrent strokes without other systemic involvement.

$\circ$ Given the patient's negative serologic testing and lack of other systemic manifestations, other inflammatory vasculitides such as ANCA-associated vasculitis, cryoglobulinemic vasculitis, and other rheumatologic conditions such as lupus, Behçet syndrome, and antiphospholipid antibody syndrome were not believed to be in keeping with the presentation.

- Large-vessel vasculitis

- GCA, a vasculitis involving primarily large vessels, was considered. ${ }^{2}$ Patients present with headaches, vision loss, jaw claudication, and systemic symptoms. Isolated intracranial involvement is rare, and ischemia tends to favor the vertebrobasilar territory. ${ }^{2}$ Diagnosis is primarily made based on temporal artery biopsy demonstrating characteristic histopathologic findings. Although our patient had a vasculopathy with elevated inflammatory markers, the predominant anterior circulation involvement and high stroke burden was not typical for GCA.

- Primary angiitis of the CNS (PACNS)

- An inflammatory vasculitis localized to the CNS, primarily involving small and medium-sized vessels, was considered. ${ }^{3}$ It presents with progressive neurologic symptoms including headache, cognitive decline, and stroke. By definition, there is no involvement of the extracranial vasculature. ${ }^{3}$ Elevated inflammatory markers and extracranial involvement are inconsistent with PACNS.

2. Noninflammatory vasculopathies

- Intracranial atherosclerotic disease (ICAD), atherosclerosis of the major intracranial circulation, is a common cause of stroke, particularly in the Asian population. On vessel imaging, it can have the appearance of diffuse beading. ${ }^{4}$ Although our patient is in the correct demographic for ICAD, the elevated inflammatory markers and lack of proximal atherosclerosis make ICAD unlikely.

- Other noninflammatory vasculopathies including reversible cerebral vasoconstriction syndrome, fibromuscular dysplasia, Susac syndrome, cerebral autosomal dominant arteriopathy with subcortical infarcts and leukoencephalopathy syndrome, and moyamoya disease were ruled out based on clinical symptoms and imaging characteristics.

3. Neoplastic/paraneoplastic vasculopathy

- Lymphoproliferative disorders involving the CNS vasculature were considered, although the CSF cytology was negative.

- Paraneoplastic syndromes may manifest as a vasculopathy. ${ }^{5}$

4. Infectious vasculopathies

- Infectious etiologies were considered unlikely given the lack of CSF pleocytosis and negative serologic testing for multiple etiologies known to cause vasculopathy, including Lyme disease, viral (HIV, varicella-zoster virus, herpes simplex virus, hepatitis B, hepatitis C), and bacterial etiologies (syphilis, endocarditis).

Given the diffuse vasculopathy with elevated inflammatory markers, there was high clinical suspicion for an inflammatory vasculitis. The patient was started on high-dose IV solumedrol after consultation with rheumatology. Brain biopsy was deferred after neurosurgical consultation, as the only accessible targets were in proximity to the motor cortex. 
Despite 2 rounds of high-dose steroids, the patient continued to have recurrent strokes with new ischemic lesions demonstrated on repeat MRI (figure 1, C).
Questions for consideration:

1. Does this change your differential?

2. What treatments would you consider now?

3. What other investigations would you order?

GO TO SECTION 3 


\section{Section 3}

Given the patient's recurrent strokes, the differential diagnosis was adjusted to include an inflammatory systemic vasculitis with CNS involvement or a lymphoproliferative disorder. Discussions among the patient, family, neurology, and rheumatology teams resulted in a decision to initiate cyclophosphamide for presumed vasculitis. Trimethoprimsulfamethoxazole (Septra) was initiated for prophylaxis of Pneumocystis jiroveci pneumonia. Investigations were continued in parallel due to the lack of diagnostic clarity, including a repeat conventional angiogram and bone marrow biopsy for chronic mild thrombocytopenia and normocytic anemia. The bone marrow biopsy was completed 2 days after initiation of cyclophosphamide and revealed normocellular marrow with adequate trilineage hematopoiesis with no evidence of lymphoma or other infiltrative pathology. Conventional cerebral angiography demonstrated ongoing beaded appearance of vessels with new involvement of the occipital arteries. Bilateral occipital artery biopsies were taken, which showed nonspecific hyperplasia and loss of internal elastic lamina.

The patient's bicytopenia worsened after treatment with cyclophosphamide and Septra, with platelets dropping to $30 \times$ $10^{9} / \mathrm{L}$ and hemoglobin dropping to $67 \mathrm{~g} / \mathrm{L}$, without signs of bleeding. Septra was stopped, but the bicytopenia worsened. A CT of the chest, abdomen, and pelvis was repeated, demonstrating subtle smooth thickening of the aortic wall (perivisceral segment), extending into the renal arteries bilaterally, suggestive of large vessel vasculitis. IV immunoglobulin was initiated for presumed autoimmune cytopenia and bone marrow biopsy was repeated 3 months after initial presentation. It showed a low level of patchy interstitial marrow infiltration by abnormal large B-lymphocytes, compatible with large B-cell lymphoma, with double expression of C-MYC and BCL2 (figure 1). CD34 stain showed 1 or 2 focal areas of possible intravascular involvement. Given the patient's

Figure 2 Bone marrow histopathology of our patient

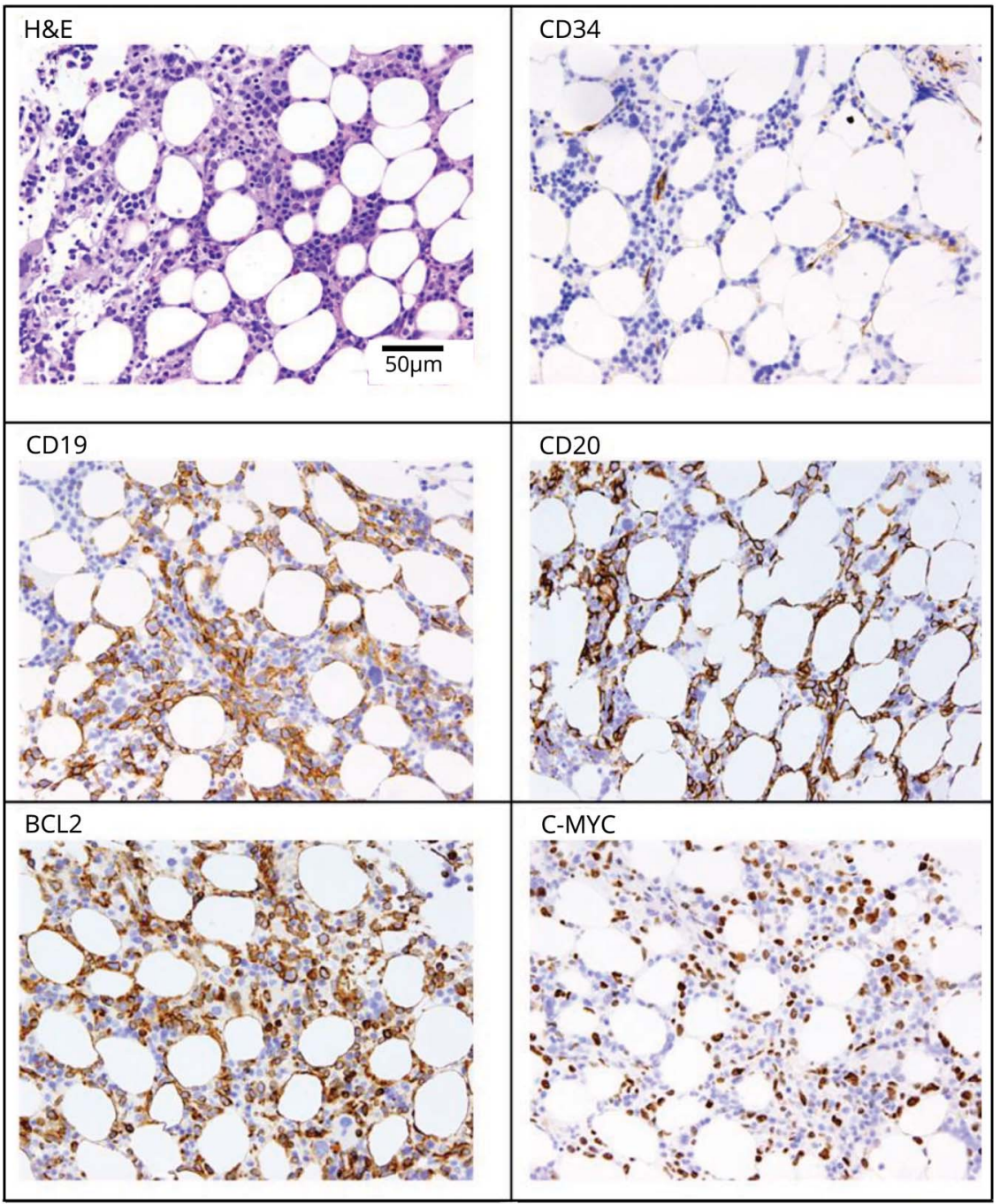

Histopathology of repeat bone marrow biopsy demonstrates diffuse large B-cell lymphoma. 
recurrent strokes and diffuse vasculopathy, a presumptive clinical diagnosis of intravascular lymphoma (IVL) was made. Due to the patient's worsening status, palliative measures were pursued, and the patient died 2 days later.

\section{Discussion}

Although large B-cell lymphoma may be preceded by paraneoplastic vasculopathy, ${ }^{5}$ the eventual diagnosis in this case was probable IVL, which is a rare lymphoma variant restricted to the vascular lumina that preferentially affects the CNS and skin. ${ }^{6}$ It is an aggressive disease that can obstruct arterial flow, causing ischemia in various organs, including the brain. The estimated incidence is 0.5 cases $/ 1,000,000$, and it is notoriously difficult to diagnose, with $>50 \%$ of patients diagnosed at postmortem examination. ${ }^{7}$ Clinical presentations seem to vary depending on ethnic background, thus classification of IVL has been divided into Western and Asian variants. ${ }^{8}$ In Western populations, CNS and skin involvement are commonly seen. Sites such as bone marrow, spleen, and liver are involved in $26 \%-32 \%$ of cases. In contrast, less than $27 \%$ of Asian patients with IVL will have neurologic and cutaneous involvement. Instead bone marrow involvement is more common and more than $50 \%$ will also involve the spleen or liver. Among Asian patients with IVL, the most common CNS presentation overall is cognitive impairment or dementia, which accounts for $60 \%$ of all CNS presentations. Stroke-like symptoms are reported in $7.6 \%$ of cases. ${ }^{9,10}$

The diagnosis of IVL is made by identifying large lymphoma cells within small to medium-sized blood vessels (figure 2). ${ }^{4}$ When the diagnosis is suspected, it is recommended to obtain multiple skin biopsies of involved and uninvolved areas. Skin biopsy was not considered in our case because tissue samples had been obtained of other clinically involved areas. Brain biopsy and biopsies of cranial vasculature may also be diagnostic, though the feasibility of these procedures will depend on the areas involved and risks of morbidity. If extracranial organ dysfunction is prominent, diagnostic specimens from those sites should be pursued. Unlike other lymphoma subtypes, involvement of the bone marrow, lymph nodes, peripheral blood, and CSF is rare, making definitive diagnosis challenging. ${ }^{8}$

There is no optimal treatment approach for IVL as many cases are not discovered until wide dissemination, and the clinical course is rapidly progressive. Chemotherapeutic agents are often used, particularly anthracycline-based regimens. The overall prognosis is much worse than that of classic diffuse large B-cell lymphoma. ${ }^{8}$

Our case speaks to the challenge of diagnosing IVL, but illustrates that it should be considered in patients with a progressive vasculopathy involving small and medium-sized vessels that does not respond to immunosuppression.

\section{Study funding}

No target funding reported.

\section{Disclosure}

R. Lun, N. Niznick, R. Padmore, J. Mack, M. Shamy, and G. Stotts report no relevant disclosures. D. Blacquiere was a site Principal Investigator for studies with Bayer, BoehringerIngelheim, and Servier Canada. Go to Neurology.org/ $\mathrm{N}$ for full disclosures.

\begin{tabular}{|c|c|c|}
\hline Name & Location & Contribution \\
\hline $\begin{array}{l}\text { Ronda Lun, } \\
\text { MD }\end{array}$ & $\begin{array}{l}\text { Division of Neurology, } \\
\text { Department of Medicine, } \\
\text { The Ottawa Hospital, } \\
\text { Canada }\end{array}$ & $\begin{array}{l}\text { Obtaining consent, direct } \\
\text { involvement in patient } \\
\text { care, creation of figures, } \\
\text { drafting and revising the } \\
\text { manuscript }\end{array}$ \\
\hline $\begin{array}{l}\text { Naomi } \\
\text { Niznick, MD }\end{array}$ & $\begin{array}{l}\text { Division of Neurology, } \\
\text { Department of Medicine, } \\
\text { The Ottawa Hospital, } \\
\text { Canada }\end{array}$ & $\begin{array}{l}\text { Direct involvement in } \\
\text { patient care, drafting and } \\
\text { revising the manuscript }\end{array}$ \\
\hline $\begin{array}{l}\text { Ruth } \\
\text { Padmore, } \\
\text { MD, PhD, } \\
\text { FRCPC }\end{array}$ & $\begin{array}{l}\text { Division of } \\
\text { Hematopathology, } \\
\text { Department of Pathology } \\
\text { and Laboratory Medicine, } \\
\text { The Ottawa Hospital, and } \\
\text { Eastern Ontario Regional } \\
\text { Laboratory Association, } \\
\text { Canada }\end{array}$ & $\begin{array}{l}\text { Creation of } \\
\text { hematopathology figures, } \\
\text { editing the manuscript }\end{array}$ \\
\hline $\begin{array}{l}\text { Jonathan } \\
\text { Mack, MD, } \\
\text { MSc, FRCPC }\end{array}$ & $\begin{array}{l}\text { Division of Hematology, } \\
\text { Department of Medicine, } \\
\text { The Ottawa Hospital, } \\
\text { Canada }\end{array}$ & $\begin{array}{l}\text { Direct involvement in } \\
\text { patient care, editing the } \\
\text { manuscript }\end{array}$ \\
\hline $\begin{array}{l}\text { Michel } \\
\text { Shamy, MD, } \\
\text { MA, FRCPC }\end{array}$ & $\begin{array}{l}\text { Division of Neurology, } \\
\text { Department of Medicine, } \\
\text { The Ottawa Hospital, } \\
\text { Canada }\end{array}$ & $\begin{array}{l}\text { Direct involvement in } \\
\text { patient care, editing the } \\
\text { manuscript }\end{array}$ \\
\hline $\begin{array}{l}\text { Grant Stotts, } \\
\text { MD, FRCPC }\end{array}$ & $\begin{array}{l}\text { Division of Neurology, } \\
\text { Department of Medicine, } \\
\text { The Ottawa Hospital, } \\
\text { Canada }\end{array}$ & $\begin{array}{l}\text { Direct involvement in } \\
\text { patient care, editing the } \\
\text { manuscript }\end{array}$ \\
\hline $\begin{array}{l}\text { Dylan } \\
\text { Blacquiere, } \\
\text { MD, MSc, } \\
\text { FRCPC }\end{array}$ & $\begin{array}{l}\text { Division of Neurology, } \\
\text { Department of Medicine, } \\
\text { The Ottawa Hospital, } \\
\text { Canada }\end{array}$ & $\begin{array}{l}\text { Design and } \\
\text { conceptualization of } \\
\text { manuscript, direct } \\
\text { involvement in patient } \\
\text { care, editing the } \\
\text { manuscript }\end{array}$ \\
\hline
\end{tabular}

\section{References}

1. Forbess L, Bannykh S. Polyarteritis nodosa. Rheum Dis Clin N Am 2015;41:33-46.

2. Samson M, Jacquin A, Audia S, et al. Stroke associated with giant cell arteritis: a population-based study. J Neurol Neurosurg Psychiatry 2015;86:216-221.

3. Birnbaum J, Hellmann DB. Primary angitis of the central nervous system. Arch Neurol 2009;66:704-709.

4. Qureshi AI, Caplan LR. Intracranial atherosclerosis. Lancet 2014;383:984-998.

5. Diniz SB, Abalo-Lojo JM, Chahud F, Ugradar S, Cruz AAV. Systemic diffuse large B-cell lymphoma presenting as bilateral orbital vasculopathy. Ophthal Plast Reconstr Surg 2019;35:e6.

6. Momota H, Narita Y, Miyakita Y, Shibui S. Intravascular lymphoma of the central nervous system presenting as multiple cerebral infarctions. Nagoya J Med Sci 2012; 74:353-358.

7. Usuda D, Arahata M, Temaru R, et al. Autopsy-proven intravascular lymphoma presenting as rapidly recurrent strokes. Case Rep Oncol 2016;9:148-153.

8. Ponzoni M, Ferreri AJM, Campo E, et al. Definition, diagnosis, and management of intravascular large B-cell lymphoma: proposals and perspectives from an international consensus meeting. J Clin Oncol 2007;25:3168-3173.

9. Intravascular Large Cell Lymphoma. UpToDate. www.uptodate.com/contents/intravascular-large-cell-lymphoma?search=intravascular\%20lymphoma\&source=search_result\&selectedTitle $=1 \sim 22$ \&usage_type $=$ default\&display_rank=1. Accessed April 7, 2019.

10. Fonkem E, Dayawansa S, Stroberg E, et al. Neurological presentations of intravascular lymphoma (IVL): meta-analysis of 654 patients. BMC Neurol 2016;16:9. 


\section{Neurology}

\section{Clinical Reasoning: Recurrent strokes secondary to unknown vasculopathy Ronda Lun, Naomi Niznick, Ruth Padmore, et al.}

Neurology 2020;94;e2396-e2401 Published Online before print May 15, 2020

DOI 10.1212/WNL.0000000000009534

\section{This information is current as of May 15, 2020}

\section{Updated Information \& Services}

References

Subspecialty Collections

Permissions \& Licensing

\section{Reprints}

including high resolution figures, can be found at: http://n.neurology.org/content/94/22/e2396.full

This article cites 9 articles, 2 of which you can access for free at: http://n.neurology.org/content/94/22/e2396.full\#ref-list-1

This article, along with others on similar topics, appears in the following collection(s):

All Cerebrovascular disease/Stroke

http://n.neurology.org/cgi/collection/all_cerebrovascular_disease_strok e

\section{Hematologic}

http://n.neurology.org/cgi/collection/hematologic

Infarction

http://n.neurology.org/cgi/collection/infarction

Vasculitis

http://n.neurology.org/cgi/collection/vasculitis

Information about reproducing this article in parts (figures,tables) or in its entirety can be found online at:

http://www.neurology.org/about/about_the_journal\#permissions

Information about ordering reprints can be found online:

http://n.neurology.org/subscribers/advertise

Neurology ${ }^{\circledR}$ is the official journal of the American Academy of Neurology. Published continuously since 1951, it is now a weekly with 48 issues per year. Copyright () 2020 American Academy of Neurology. All rights reserved. Print ISSN: 0028-3878. Online ISSN: 1526-632X.

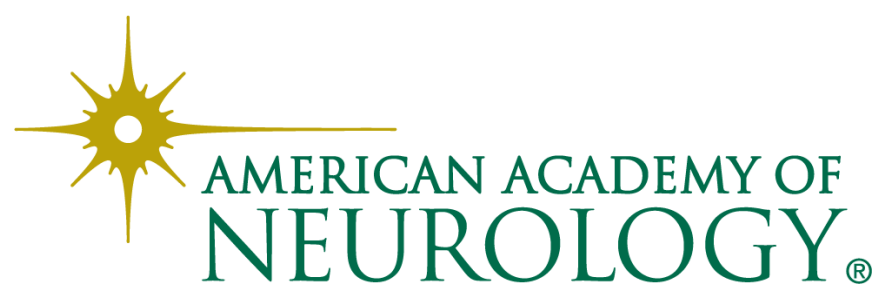

